\title{
Arm Wrestling around Air Quality and Effective Judicial Protection. Can Arrogant Resistance to EU Law-related Orders Put You in Jail?
}

Judgment of the Court (Grand Chamber) of 19 December 2019 in Case C-752/18 - Deutsche Umwelthilfe eVvFreistaat Bayern

\author{
Delphine Misonne \\ FNRs Research Associate, Université Saint-Louis-Bruxelles, Belgium \\ delphine.misonne@usaintlouis.be
}

\begin{abstract}
In the judgment Deutsche Umwelthilfe (C-752/18) of December 2019, the Court of Justice of the European Union (ECJ) addresses the situation where a referring court has already ordered a public authority to adopt traffic bans, based upon the need to comply with Directive 2008/50 on air quality, but is confronted, together with the non-governmental organization which is at the initiative of the lawsuit, to the public authority's persistent refusal to comply with that injunction, even though it has become final.

In such awkward situation and due to the lack of success of other avenues, is a national court entitled - and possibly even obliged - to impose coercive detention on officials, by virtue of the right to an effective remedy and the obligation to ensure effective legal protection in the fields covered by EU law, asked the referring Court?

It is not surprising that the Court of Justice sat as the Grand Chamber for delivering the preliminary ruling. The case is a landmark on the right to an effective remedy and on the right to liberty, in a context of procedural autonomy. The case is also essential in the way it embraces human health and adds a higher step in the ascending line gradually constructed by the ECJ on the binding force of EU law on air quality standards.

The ECJ decides that EU law only empowers and even obliges a national court to have recourse to the privation of liberty of a public official, like a Minister-President, if this is provided for in a domestic legal basis, which is sufficiently accessible, precise and foreseeable in its application.
\end{abstract}


This contribution observes that, if the judgement may look like a victoire à la Pyrrhus for the environmental association and if it confirms that EU environmental law remains systemically dependent upon the choices made at domestic level on enforcement matters, the judgment also truly consolidates the right to effective judicial protection and the right to an effective remedy, in more normal circumstances and when human health is in the balance. It also cements the direct effect of Directive 2008/50 on ambient air quality and associated rights for individuals.

\section{Keywords}

effective judicial protection - right to liberty - primacy - air quality - diesel ban

\section{Introduction $^{1}$}

Low-emission zones and diesel bans are making headlines nowadays. As long as the car industry does not switch to truly clean vehicles, cities and regions in the European Union will have no many other choices, in order to fulfill their obligation to adequately protect ambient air quality and public health, than to restrict the use of cars. If they do not adopt restricting measures, citizens or associations will remind them to do so, based on the necessity to comply with Directive 2008/50/EC of the European Parliament and of the Council of 21 May 2008 on ambient air quality and cleaner air for Europe, ${ }^{2}$ which imposes the respect of air quality standards and the need to adopt plans apt to meet such standards as soon as possible, where exceedances are observed.

Through the advances of case-law, ${ }^{3}$ individuals and associations are now entitled to claim from public authorities the adoption of such air pollution plans, if needed by bringing an action before the competent domestic courts. ${ }^{4}$ Moreover, it has now been made clear by the Court of Justice of the European Union (ECJ) that it is for the domestic courts having jurisdiction, should a case be brought before them, to take, with regard to the national authority,

1 Case C-752/18 Deutsche Umwelthilfe eVvFreistaat Bayern [2019] ECLI:EU:C:2019:1114.

2 OJ L 152, 11.6.2008, pp. 1-44.

3 D. Misonne, 'The emergence of a right to clean air: Transforming European Union law through litigation and citizen science', RECIEL 2020, pp. oo:1-12; L. Krämer, ‘480.00o Dead per Year are Enough: The CJEU Opens a New Way to Better Enforce Air Quality Laws', JEEPL 2018 15/1, pp. 111-121; A. Ryal, 'Enforcing EU Environmental Law against Member States: Air Pollution, National Courts and the Rule of Law', EJJR 2015 (305), p. 308.

4 Case C-237/o7 Janecek [2008] ECLI:EU:C:2008:447. 
any necessary measure, such as, if provided for by national law, an order in the appropriate terms, so that the authority establishes the plan required by the directive in accordance with the settled conditions. ${ }^{5}$

However, obtaining such a judicial order does not necessarily mean reaching the end of the judicial story. As the facts of case C-752/18 Deutsche Umwelthilfe eVv Freistaat Bayern of 19 December 2019 demonstrate, it occurs that public officials not only resist, but also express a manifest intention not to comply with judicial decisions on EU law and, more specifically, air quality, which have become final. The Land of Bavaria refused to introduce a ban on diesel vehicles, preferring to pay unsubstantial financial penalties instead of adopting those measures that were prescribed by a judge to protect air quality.

Munich is a city where major advances on the front of ambient air quality caselaw have been booked during the last decade, unfortunately because, like in many other European cities, there were many questions to be asked on the relation between air quality and traffic, but also because there were active and resolute citizens ready to ask for answers. Munich is indeed where the Janecek case emerged, in 2008. ${ }^{6}$ In that preliminary ruling case bearing the name of a citizen distressed by the consistently polluted air in its area, at a time where locus standi was still locked for non-governmental organizations on environmental matters in Germany, the ECJ made clear that where there is a risk that the limit values or alert thresholds may be exceeded, persons directly concerned must be in a position to require the competent national authorities to draw up an action plan, if necessary by bringing an action before the competent courts. The case opened doors for the judicial review of plans the purpose of which is to protect ambient air quality.

A few years later, because the limit value for nitrogen dioxide $\left(\mathrm{NO}_{2}\right)$ set by Directive 2008/50, was still being exceeded at numerous places within the city of Munich, Deutsche Umwelthilfe, a German non-governmental organization, ${ }^{7}$

5 Case C-404/13 ClientEarth [2014] ECLI:EU:C:2014:2382, para. 58; Case C-723/17 Craeynest and Others [2019] ECLI:EU:C:2019:533, para 56, adding 'if provided for by national law'. See K. Pedrosa, The Decentralised Enforcement of the Provisions on Measurement and Assessment of Air Quality under Directive 2008/50/EC, JE E PL 2020, 17, pp. 247-261.

6 Case C-237/07 Janecek [2008] ECLI:EU:C:2008:447.

7 Which, based on the Aarhus Convention, now got empowered to initiate group litigation in environmental matters in Germany. 
claimed before the competent administrative Court the judicial review of the supposedly inadequate air quality plans. By judgment of 9 October 2012, the Administrative Court of Munich enjoined the Land of Bavaria to amend the air quality plan applicable to the city of Munich (which corresponds to the air quality plan' referred to in Article 23 of Directive 2008/50), in such a way as to include the measures necessary in order for the limit value set for nitrogen dioxide to be complied with as soon as possible. But the air quality plan was not changed.

By order of 21 June 2016, the same Court threatened the Land of Bavaria with a financial penalty of EUR 10000 if it did not comply with that injunction within one year from service of the order. The Land of Bavaria appealed against that order to the Higher Administrative Court of Bavaria which, on 27 February 2017, also threatened the Land of Bavaria with financial penalties totaling EUR 10000 , payable in the event that the Land failed to take the necessary steps to bring the values within the limits, which included the introduction of a traffic ban on certain diesel vehicles in certain urban zones.

Since the Land of Bavaria did not comply in full with the obligations flowing from the order of 27 February 2017, the Administrative Court of Munich, again, upon application of Deutsche Umwelthilfe, required the Land of Bavaria, by order of 26 October 2017, to pay a fresh financial penalty of EUR 4000 , which it did, without imposing the required restrictions on traffic.

On the contrary, representatives of the Land of Bavaria, including its Minister-President, publicly stated their intention not to comply with the aforementioned obligations relating to the imposition of traffic bans. They consider it disproportionate to ban diesel vehicles from certain roads or sections of road, and accordingly that it is not appropriate to take such measures. ${ }^{8}$

To sum up what already looks like getting down a rabbit hole, from 2012 onwards, the association accumulated successes and judicial orders, including the need to impose a traffic ban on certain diesel vehicles in Munich for meeting EU law requirements on air quality. But, in practice, all to no much avail. The Land of Bavaria preferred to pay the ridiculously low financial penalties ${ }^{9}$

8 Saugmandsgaard Øe, para 21.

9 On the explanation of such low amounts, see the AG's opinion, para 37 to 39 . As is apparent from the referring court's presentation of the legal background, the measures available for the enforcement of judgments, in German civil law, include financial penalties, orders for the performance of the obligation by a third party, and committal orders. As for German administrative law, this allows for financial penalties to be imposed with a view to compelling the administration to comply with the direction issued to it in the judicial decision. Such penalties are lower in amount than they are in civil law. If financial penalties prove ineffective then it is possible, according to the national court, to have recourse to the civil law rules. which 
which, even if the prescribed amounts were higher, would not have reduced the Land's resources anyhow. ${ }^{10}$

Deutsche Umwelthilfe resisted such attitude and, again, fought back. On the basis of explicit provisions of the German Civil Procedure Code, ${ }^{11}$ it dared to ask the administrative court of Munich for the committal to prison of the Minister for the Environment and for Consumer Protection of the Land of Bavaria or, failing that, the Minister-President of the Land. The administrative Court dismissed the claim, because an old jurisprudence of the German Constitutional Court made clear that such committal was actually not applicable to public officials of the executive, even if national law does in principle provide for the institution of detention for the purpose of enforcing judicial decisions.

But what does EU law itself require, asked Deutsche Umwelthilfe? Again, it appealed to the Higher Administrative Court of Bavaria, which referred the question to the ECJ for a preliminary ruling. In so doing, a clever loop was made, meant to clarify whether, by virtue of EU law, the administrative court could actually set aside the restrictive position adopted by the German constitutional court and, based upon EU law, impose another jurisprudence.

\section{3} The Question

The Higher administrative Court of Bavaria asked whether, based on a series of Treaty and Charter provisions, and most importantly also the Aarhus

provide, inter alia, for financial penalties of up to EUR 25 000, as opposed to EUR 10000 . Committal orders cannot, however, be made against public officials. As indicated in point 27 of the Opinion, this is said to follow from German constitutional law, as interpreted by the Bundesverfassungsgericht (Federal Constitutional Court).

10 Such penalties would be paid by entering the amount fixed by the court as a debit item under a given heading of the Land's budget and crediting the same amount to its central funds. In clear, such public money comes out of one pocket only to return to basically the same pot.

11 Paragraph 888(1) and (2) of book eight of the German Civil Procedure Code states that: ' 1 .Where an act can only be performed voluntarily by the person subject to the obligation, and not by a third party, and an application is made, the court of first instance hearing the case shall, with a view to ensuring that the person concerned performs the obligation, impose a suspended financial penalty and, in the event that the penalty becomes payable but payment cannot be obtained make an order for committal to prison, or make such a committal order. A financial penalty may not exceed EUR 25000 in amount. The provisions of Chapter 2 relating to deprivation of liberty are applicable mutatis mutandis to committal orders. 2. No advance warning shall be given of such coercive orders.' 
Convention, a German court is entitled - and possibly even obliged - to impose detention on persons involved in the exercise of the official authority of a German Federal Land in order thereby to enforce EU law on ambient air quality, in such special circumstances where threats and imposition of financial penalties were to no avail, no other coercive instruments are available and officials publicly declared they did not intent to comply with judicial orders.

It seeked, in essence, ${ }^{12}$ to ascertain whether EU law, in particular the first paragraph of Article 47 of the Charter, must be interpreted as meaning that, in circumstances in which a national authority persistently refuses to comply with a judicial decision enjoining it to perform a clear, precise and unconditional obligation flowing from EU law, in particular from Directive 2008/50 on air quality, EU law empowers or even obliges the national court having jurisdiction to order the coercive detention of office holders involved in the exercise of official authority.

Interestingly, the clear, precise and unconditional obligation flowing from EU law targets the obligation to take measures necessary to comply with the limit values set by Directive 2008/50, including the imposition of traffic bans in respect of certain diesel vehicles in various urban zones. ${ }^{13}$

What regards the appropriateness of diesel bans, in direct relation to the requisites of Article 23 of Directive 2008/50, the Federal Administrative Court in Leipzig, which hears appeals directed against decisions of the High Administrative Courts (including that of Bavaria), did already decide that they were appropriate, upon conditions. In a 2018 judgement concerning the city of Stuttgart, the highest administrative court asserted that Diesel bans were suitable measures in order to meet EU law and that they comply with the proportionality principle, if they are introduced gradually over time according to the age and exhaust emission behavior of the vehicles concerned and include exceptions. ${ }^{14}$ Based on the available expertise, it decided that the lower Court in any event rightly concluded that a traffic ban on the motor vehicles can be lawfully ordered and that its permissibility results from EU law. ${ }^{15}$ This is the reason why the defiant attitude of the Bavarian authorities towards the judicial order to impose a traffic ban in Munich was even more objectable and that the very relevance of such bans was not an issue in the present case. ${ }^{16}$

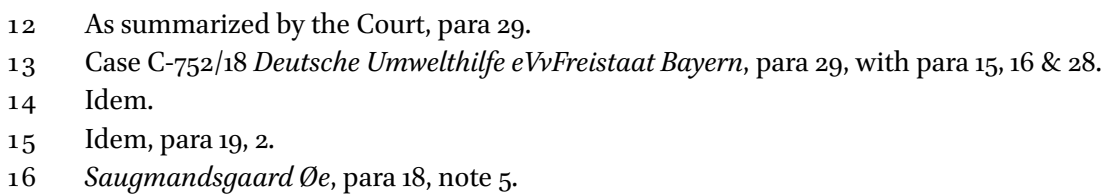


Enforcement of EU environmental law has always been the parent pauvre and the obliterated dimension of EU Environmental policies. The case must be read while keeping that typical feature in mind. ${ }^{17}$ Except for a few advances here and there, like the need to ensure that a list of conducts constitutes a criminal offence ${ }^{18}$ or an obligation to set up systems of environmental inspections ${ }^{19}$ - or, of course, the true revolution provoked by the Aarhus Convention on the theer pillars, among which access to justice for associations,$-{ }^{20}$ many environmental directives or regulations, and typically the 2008/50 Directive, restrain to a generic delegation: "Member States shall lay down the rules on penalties applicable to infringements of the national provisions adopted pursuant to this Directive and shall take all measures necessary to ensure that they are implemented. The penalties provided for must be effective, proportionate and dissuasive". ${ }^{21}$

On the meaning of those terms 'all necessary measures', the recent Craeynest case already recalled that, in the absence of EU rules, it is for the domestic legal system of each Member State to designate the courts and tribunals having jurisdiction and to lay down the detailed procedural rules governing actions for safeguarding rights which individuals derive from EU law, such as Directive 2008/50.22 The novel question in Deutsche Umwelthilfe was whether the

17 L. Squintani, Addressing the (Lack of) Effectiveness of Environmental Law and the Gap between Law in the Books and Law in Action, Journal For European Environmental \& Planning Law 2020, 17(2), pp. 133-135; D.Misonne, 'EU Dieselgate: unveiling the weirdness of the EU's attitude to compliance on environmental matters', ELNI 2018, 2, pp. 52-59 \& RGA online, December 2019, available at http://rgaonline.it ; P. Wenneras, The Enforcement of EC Environmental Law, Oxford, OUP, 2007; L. Krämer, Deficits in application of EC Environmental law and its causes, Sweet \& Maxwell, Londres, 1997, p. 1; M. Heldemann-Robinson, Environmental Inspections and the EU: Securing an Effective Role for a Supranational Union Legal Framework, Transnational, Environmental Law, 2017, vol.6, pp. 31-58.

18 Directive 2008/99/EC of the European Parliament and of the Council of 19 November 2008 on the protection of the environment through criminal law, oJ L 328, 6.12.2008, pp. 28-37. On the sensitive history of the directive, see Case C-176/o3 Commission v Council [2005] I-7879, pronounced in a pre-Lisbon Treaty era.

19 Directive 2010/75/EU of the European Parliament and of the Council of 24 November 2010 on industrial emissions (integrated pollution prevention and control), of $L$ 334, 17.12.2010, pp. 17-119.

20 J.Jendrośka, Access to Justice in the Aarhus Convention - Genesis, Legislative History and Overview of the Main Interpretation Dilemmas, JEE PL 2020, ... 17.4, pp. 1-373 ff.

21 Art.30, italics added.

22 Case C-723/17 Craeynest and Others [2019] ECLI:EU:C:2019:533, para 54, with reference to the Janecek (para $38 \& 39$ ) and Client Earth cases (para 55, 56 \& 58 ). 
national court's obligation to take all necessary measures to ensure compliance with Directive 2008/50 extends, in such a case, to imposing a measure involving the privation of liberty of public officials, in order to secure compliance with the principle of effectiveness of EU law and the right to an effective remedy, even if this is not fully in adequacy with national law. ${ }^{23}$

If, in the absence of harmonization of national enforcement mechanisms, the details of implementation are governed by the internal legal order of the Member States by virtue of the principle of procedural autonomy of those States, ${ }^{24}$ such autonomy does nevertheless not mean entire discretion. Among the established limits and criteria, besides a principle of equivalence ${ }^{25}$ and a principle of effectiveness, ${ }^{26}$ reigns indeed the need to ensure compliance with the right to an effective remedy and to a fair trial, as enshrined in Article 47 of the Charter of Fundamental Rights of the European Union, which constitutes a reaffirmation of the principle of effective judicial protection. ${ }^{27}$

\section{The Judgment}

\section{1}

\section{An Enhanced Right to an Effective Remedy}

When Member States implement EU law, they are required to ensure compliance with the right to an effective remedy which, explains the Grand Chamber, is enshrined in both the Charter of Fundamental Rights and the Aarhus Convention, comforting the view that Article 47 Charter has now really turned out to be an autonomous standard of judicial control and confirming the Brown Bear II precedent on the legal effect of the Aarhus Convention on the EU legal order. ${ }^{28}$ With regard to the Aarhus Convention, the Grand Chamber also reaffirms that, in order to ensure effective judicial protection in the fields covered by EU environmental law, it is for the national court to interpret its national

23 Case C-752/18 Deutsche Umwelthilfe eVvFreistaat Bayern, para 28 \& 40-41.

24 Case C-752/18 Deutsche Umwelthilfe eVvFreistaat Bayern, para 33.

25 The detailed rules provided for must not be less favourable than those governing similar domestic situations.

26 The detailed rules must not make it impossible in practice or excessively difficult to exercise rights conferred by EU law. See, to that effect, Case C-71/14 East Sussex County Council [2015] ECLI:EU:C:2015:656, para 52; case C-572/16 INEOS Köln, C-572/16 [2018] EU:C:2018:100, para 42.

27 Case C-348/16 Sacko [2017] ECLI:EU:C:2017:591, para 31; Case C-73/16 Puškár [2017] ECLI :EU:C:2017:725, para 59.

28 Para 34. See L. Ankersmit, 'Brown Bears II: Aarhus and the Charter show their teeth', European law Blog, 24 March 2017, available at https://europeanlawblog.eu/2017/03/24/brown -bears-ii-aarhus-and-the-charter-show-their-teeth/. 
law in a way which, to the fullest extent possible, is consistent both with the objectives laid down in Article 9(3) and (4) of the Aarhus Convention and with the objective of effective judicial protection of the rights conferred by EU law. ${ }^{29}$

The Grand Chamber insists on the need for the national Courts to have the appropriate means of securing observance of their judgements, based on previous case-law already fleshing out what Article 47 now means, ${ }^{30}$ as a formally binding right and not only a mere principle flowing out of the European Convention on Human Rights. ${ }^{31}$

National legislation which results in a situation where the judgment of a court remains ineffective because that court does not have any means of securing observance of the judgment fails to comply with the essential content of the right to an effective remedy; that right would be illusory if a Member State's legal system were to allow a final, binding judicial decision to remain ineffective to the detriment of one party; ${ }^{32}$ the fact that the public authorities do not comply with a final, enforceable judicial decision deprives that provision of all useful effect, hammers the ECJ at the inspiration of the Strasbourg's jurisprudence. ${ }^{33}$

Above all, and this is a truly innovative element that further completes the upward trend already firmly established by the court's case law on air quality, ${ }^{34}$ the Grand Chamber affirms that the right to an effective remedy is "all the more important" because, in the field covered by Directive 2008/50, "failure to adopt the measures required by that directive would endanger human health". ${ }^{35}$ Risks caused to human health definitely push beyond usual standards the

29 By reference to case C-240/og Lesoochranárske zoskupenie [2011] ECLI:EU:C:2011:125, para 50 and 51.

30 By reference to case C-556/17 Torubarov [2019] ECLI:EU:C:2019:626, para 69.

31 F. Krenc, 'Droit à un recours effectif et à accéder à un tribunal impartial', in: F.Picod, C. Rizcallah \& S. Van Drooghenbroeck, Charte des droits fondamentaux de l'Union européenne, commentaire article par article, p. 984 .

32 Cases C-205/15 Toma and Biroul Executorului Judecătoresc Horațiu-Vasile Cruduleci [2016] ECLI:U:C:2016:499, para 43 and the case-law cited, and case C-556/17 Torubarov [2019] ECLI:EU:C:2019:626, para 57.

33 ECtHR, 19 March 1997, Hornsbyv. Greece, CE:ECHR:1997:0319JUDoo1835791, para 41 and 45.

34 D. Misonne, 'The emergence of a right to clean air', op.cit.

35 With reference to Janecek, para 38. Emphasis added. The Janecek case does not contain the same wording. Para 38 mentions: "Thus, the Court has held that, whenever the failure to observe the measures required by the directives which relate to air quality and drinking water, and which are designed to protect public health, could endanger human health, the persons concerned must be in a position to rely on the mandatory rules included in those directives (see Case C-361/88 Commission v Germany; Case C-59/89 Commission v Germany; and Case C-58/89 Commission v Germany)". 
interpretation of the directive on ambient air quality - and, more broadly, environmental law - and enhance the credit it deserves. ${ }^{36}$

If apparently exceptional, the case is not inconsequential, explained Advocate General Saugmandsgaard Øe. On the contrary, the refusal of public officials of the Land of Bavaria to comply with the final judicial decisions at issue in the main proceedings may have serious consequences for people's health and lives and for the rule of law. Respect for the rule of law is required of all EU citizens, and first and foremost of representatives of the State, given the particular responsibilities which - precisely because of their functions - they have in that area, he insisted. ${ }^{37}$

\subsection{Could You Oblige Me, Please?}

The referring court considers that it cannot secure compliance with the principle of effectiveness of EU law and the right to an effective remedy unless $E U$ law empowers or even obliges it to disregard the reasons of a constitutional nature which, in its view, prevent the application of coercive detention to office holders involved in the exercise of official authority. ${ }^{38}$

Since financial penalties in a total amount of EUR 10 ooo have proved ineffective, and since the imposition of higher penalties of up to EUR 25000 cannot be expected to produce the desired effect either, the referring court considers it appropriate to make a committal order. That court indicates that this would involve applying a decision of the Federal Constitutional Court of $1999,{ }^{39}$ under which consideration may be given to the use of the more coercive measures available in German civil law, while disapplying another decision of that court, of 1970, under which committal orders may not be made against public officials. The lack of a clear and precise law which meets certain formal requirements in relation to such persons prevented such orders from being made against them, it is contended. Paragraph 888 of the Civil Procedure Code, it is argued, does not meet those requirements, and German courts have never imposed a measure involving deprivation of liberty on a public official on the basis of that provision. Because the coercive means available to it in national law are not adequate to ensure that the administration complied with its judgment and that EU law is fully effective, explains the referring Court, ${ }^{40}$ the question arose as to whether the national court must disapply a current

36 D. Misonne, 'The emergence of a right to clean air: Transforming European Union law through litigation and citizen science', RECIEL 2020.

37 Saugmandsgaard Øe, para 40 \& 49.

38 Para 41.

39 Para 66 of the Opinion.

$40 \quad$ By analogy to the Torubarov case, observes the AG in its opinion, para 62. 
domestic doctrine law so as to give full effect to Article 23 of Directive 2008/50 and Article 47 of the Charter.

Where it is unable to interpret national law in compliance with the requirements of EU law, a national court hearing proceedings against a public authority is required, under the principle of primacy of EU law, to disapply any provision of national law which is contrary to a provision of EU law with direct effect (a provision of EU law which is sufficiently clear, precise and unconditional to confer on individuals a right capable of being relied on as such before a national court).$^{41}$ Interestingly, the Court does not discuss the assertion that Article 23 of Directive 2008/50 and Article 47 of the Charter have such direct effect. ${ }^{42}$ In a note, ${ }^{43}$ the AG explains that, in relation to Article 23 of Directive 2008/50, the Court has held that the provision imposes a clear obligation to establish an air quality plan that complies with certain requirements, an obligation capable of being relied on by individuals as against public authorities, referring to the Client Earth case of 2014. ${ }^{44}$ With regard to Article 47 of the Charter, the Court has held that in the context of a dispute relating to a situation governed by EU law, that article is sufficient in itself and does not need to be made more specific by provisions of EU or national law in order to confer on individuals a right which they may rely on as such..$^{45}$

However, in the Deutsche Umwelthilfe case, the AG suggested that there may be limits to giving full effectiveness to EU law, including Article 23 of Directive 2008/50 and Article 47 of the Charter, in such exceptional circumstances where compliance hurts the basic fundamental right to liberty. ${ }^{46}$

\subsection{The Horizontal Conditions of Primacy}

It is settled case-law that, according to the principle of primacy, any form of directly applicable Union law can render inapplicable any conflicting national law irrespective of its rank, even constitutional. ${ }^{47}$ However, while reaffirming

$41 \quad$ Para 42.

42 L. Squintani \& J. Lindeboom, The Normative Impact of Invoking Directives: Casting Light on Direct Effect and the Elusive Distinction Between Obligations and Mere Adverse Repercussions. Yearbook of European Law 2019, 38, pp. 18-72.

43 Para 64 of the Opinion, note 31.

44 Case C-404/13 ClientEarth [2014] ECLI:EU:C:2014:2382.

45 Reference being made to Case C-414/16 Egenberger [2018] ECLI:EU:C:2018:257, para 78, and Case C-556/17 Torubarov [2019] , ECLI:EU:C:2019:626, para 56.

46 Saugmandsgaard Øe, para 49.

47 Rules of national law, even of a constitutional order, cannot be allowed to undermine the unity and effectiveness of Union law, see case C-409/06 Winner Wetten GmbH c. Bürgermeisterin der Stadt Bergheim [2010] ECLI:EU:C:2010:503, para 61; Case C-11/7o Internationale Handelsgesellschaft [1970] ECR 1125, para 3. 
the prevalence of EU law upon national measures and referring to Simmenthal and associated case-law on the obligation for a national Court to disapply any provision of national law which is contrary to a provision of EU law with direct effect in the case pending before it, ${ }^{48}$ the Grand Chamber retrenches behind the need, in so doing, not to infringe another fundamental right guaranteed by EU law, the right to liberty. ${ }^{49}$

The Court displaces the question from an already settled vertical issue (the sensitive relation between EU law and a constitutional court $)^{50}$ to a horizontal intra-EU necessity to balance recognized rights, exclusively within the EU order, against each other.

As is apparent from Article 52(1) of the Charter, the right to effective judicial protection is not an absolute right and may be restricted, in particular in order to protect the rights and freedoms of others, such as the right to liberty, guaranteed by Article 6 of the same Charter. Fundamental rights at issue must thus be weighed against one another, recalls the Court. Any limitation on the exercise of the rights and freedoms recognised by this Charter must be provided for by law. Nothing but normal except for the precision that such legal basis must here be found in a domestic law. ${ }^{51}$

However, because it is not any fundamental right but the right to liberty which is in the balance, AG Saugmandsgaard Øe advised the ECJ to even enhance the requisites of Art. $5^{2}$ of the Charter by endorsing the settled case-law of the European Court of Human Rights ${ }^{52}$ according to which, to impact the right to liberty, there must exist a law empowering a court to deprive a person of his or her liberty that is sufficiently accessible, precise and foreseeable in its application in order to avoid all risk of arbitrariness. ${ }^{53}$ Those conditions indeed apply, says the Grand Chamber, in respect of any type of deprivation of liberty, including where it results from the need to enforce a penalty imposed by a judicial decision, irrespective of the possibility for the person concerned of

48 Case C-106/77 Simmenthal [1978] ECLI:EU:C:1978:49, para 21 and case C-573/17 Poptawski [2019] ECLI:EU:C:2019:530, para 58 and 61. Emphasis added.

49 Para 43.

5o We do not enter here into the controversies in a few member States on the admissibility of such established principle of primacy, when in potential conflict with national Constitutions, before or after the adoption or change of status of the EU Charter of Fundamental Rights.

$5^{1} \quad$ Para 56.

52 ECtHR, 21 October 2013, Del Rio Prada v. Spain, EC:ECHR:2013:1021JUDo04275009, paragraph 125 and the case-law cited and ECtHR of 25 June 1996, Amuurv. France, EC:EC HR:19 96:0625JUDoo1977692, para 50. Also case C-528/15 Al Chodor [2017] ECLI:EU:C:2017:213, para 38 and 40$)$.

$53 \quad$ Para 46. 
avoiding the deprivation of liberty by complying with an injunction imposed by that decision or an earlier decision. ${ }^{54}$

The Court suggests to the domestic court to determine whether the relevant national provisions meet such conditions in order to enable all risk of arbitrariness to be avoided, ${ }^{55}$ a magic trick which is also delusive as, would such domestic law exist that is sufficiently accessible, precise and foreseeable in its application to flesh out what a right to an effective remedy might mean in relation to compliance with an order imposing appropriate air quality plans, why would such question have escalated to the ECJ? From the referred question, ${ }^{56}$ it is plain that such clarity does not exist, especially with due regard of the concerned persons, the public authorities.

In accordance with Art $5^{2.1}$ Charter and because, as mentioned by the AG, a deprivation of liberty must be a measure of last resort, ${ }^{57}$ the national Court must also verify, based on the need to meet a proportionality test, if no alternatives were available, that enables the objective pursued to be attained. Recourse may be had to such an order only where there is no less restrictive measure that enables the objective pursued to be attained. ${ }^{58}$ According to the AG, it was no fully clear, in the present case, that the referring court had used all the means available to it under national law, such as financial penalties of EUR 25 ooo, potentially recurring at short intervals, or the possibility that such financial penalties could be payable to a third party. ${ }^{59}$

\subsection{EU Law Not Only Authorises, but Requires}

The Grand Chamber concludes in a ubi et orbi style that made twitter-headlines in December 2019, that it is only if the referring court were to conclude that such conditions are satisfied ( a law meeting a high standard of clarity on the deprivation of liberty of public officials in such circumstances and no alternatives) that EU law would not only authorise, but require, recourse to such a measure. ${ }^{60}$

But the reverse is even truer. Where there is no sufficiently accessible, precise and foreseeable legal basis in domestic law, EU law does not help

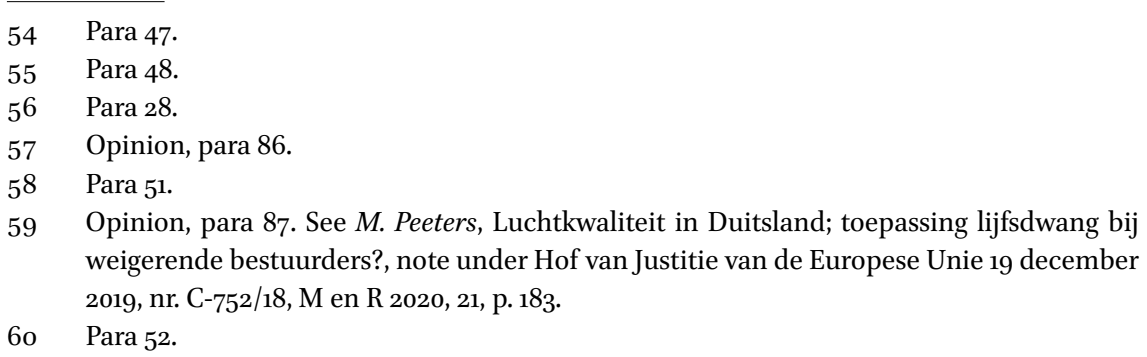


empowering national courts to have recourse to such privation of liberty, even if the public officials refuse to comply with a judicial decision enjoining it to perform a clear, precise and unconditional obligation flowing from EU law. The right to effective judicial protection is not an absolute right and may be restricted when it impacts the right to liberty.

Yet, the Court, in a pirouette, also suggested other judiciary means for pressuring the local authorities to comply with the EU-related judicial order and to force changes upon the national lawmaker.

First, the possibility that an infringement of Directive 2008/50 may be found by the Court, in an action for failure to fulfil obligations under EU law. Such infringement procedure is actually in the pipeline, as the Commission already initiated proceedings in relation to air pollution in the city of Munich. The impact of such judgment, would a breach be confirmed, could, maybe, force Germany to foresee more adequate coercive means in relation to the implementation of air quality plans.

Second, the Court even invites Deutsche Umwelthilfe to test the Frankovitch avenue, ${ }^{61}$ and engage (again) in a whole new judicial battle, from a fresh angle: the principle of State liability for loss or damage caused to individuals as a result of breaches of EU law for which the State can be held responsible, "as that principle is inherent in the system of the treaties on which the European Union is based."62 Another way to try and claim the full effectiveness of EU law and effective protection of the rights which individuals derive from it, according to the Grand Chamber, as the principle applies to any case in which a Member State breaches EU law, whichever public authority is responsible for the breach. ${ }^{63}$ The process is known as being fraught with hurdles ${ }^{64}$ but could be worth exploring due to the strength gained by the air quality standards and the resulting obligations for national authorities, who could maybe retrenches behind the lack of coherence of EU law on the regulation of air pollution. The mention is important for it connects, again, air quality to the issue of rights which individuals derive from EU law on air quality and the importance of

61 Case C-6/9o and C-9/9o, Francovich and Others [1996] EU:C:1991:428, para 35; Case C-46/93 and C-48/93 Brasserie du pêcheur and Factortame [1996] ECLI:EU:C:1996:79, para 20, 39 and 52, and case C-168/15 Tomášová [2016] ECLI:EU:C:2016:602, para 18 and the case-law cited.

$62 \quad$ Para 54.

63 Case C-168/15 Tomášová [2016] ECLI:EU:C:2016:602, para 19 and the case-law cited.

64 S. Bechtel, Of Munich Air and Prisons, analysis by Client Earth, 24 February 2020 (https:// www.clientearth.org/of-munichs-air-and-prisons-new-court-of-justice-ruling-on-effec tive-remedies). 
their full effectiveness. ${ }^{65}$ To our knowledge, such specific path has not yet been explored, even if actions based on tort law and air quality are flourishing in some countries. ${ }^{66}$

\section{$6 \quad$ Impact}

Needless to say but important to recall, the Deutsche Umwelthilfe ruling is binding. The ECJ has consistently held that a judgment in which the Court gives a preliminary ruling is binding on the national court for the purposes of the decision to be given in the main proceedings. ${ }^{67}$ It is now up to the referring court to digest the ruling and verify if the conditions are met. The odds are on the negative side and, in that regard, even if the request to order the coercive detention of public officials was in no way frivolous, the judgement might resemble to a victoire à la Pyrrhus for the environmental association.

The judgement confirms that EU environmental law remains systemically dependent on enforcement matters upon what the national regime encapsulates, even if is bound by the obligation to ensure effective judicial protection of the rights conferred by EU law, a right that is never absolute when set in a balance with the right to liberty. ${ }^{68}$ Interestingly, the Grand Chamber does not repeat the words of the AG when he evoked the large discretion of the national legislature in defining its own coercive measures, ${ }^{69}$ but suggests what an effective regime of coercive measures on air quality plans might entail, like high financial penalties that are repeated after a short time and the payment of which does not ultimately benefit the budget from which they are funded..$^{70}$

65 D. Misonne, "The emergence of a right to clean air: Transforming European Union law through litigation and citizen science', RECIEL 2020, reffering to the Leth case ( Case C-420/11 Leth [2013] ECLI:EU:C:2013:166.

66 Like France or the Netherlands.

67 Case C-446/98 Fazenda Pública [2010] ECLI:EU:C:200o:691 para 49; Press release 58/20 following the judgment of the German Constitutional Court of 5 May 2020, 8 May 2020, available at https://curia.europa.eu.

68 Para 39.

69 Conclusions of the AG, para 88. Reference is made to an article published in the Frankfurter Allgemeine Zeitung on 18 July 2019; the President of the Bundesverwaltungsgericht (Federal Administrative Court) expressed the view that a committal order was not an appropriate measure in relation to representatives of an organ of the administration, such as the Minister-President of a Land. The public would expect state and regional organs and senior officials to continue to perform all their functions.

$70 \quad$ Para 40. 
The judgement contains decisive advances on the very requisites of the right to effective judicial protection, if one can avoid being blinded by the sole sensitive issue of coercive detention which plays somehow a poisonous role in the whole chronicle.

Make the most of what you have on enforcement, says the Grand Chamber in essence, as the right to an effective remedy is all the more important because, on air quality, failure to adopt the measures required by that directive would endanger human health (and therefore subjective rights). ${ }^{71}$ This did not fall on deaf ears, as observed in the judgment of the French Conseil d'Etat, on July 10, 2020, where the highest administrative jurisdiction imposed on the State the higher ever decided financial penalty for failure to comply, on time, with a previous judicial decision meant to impose the respect of EU law on air quality standards and adequate associated planning, here also upon request of an environmental association. ${ }^{72}$

But if the national regime does not contain a law that is sufficiently accessible, precise and foreseeable in its application to flesh out the possibility to impose the coercive detention of public officials, forget it. The national court cannot order coercive detention solely on the basis of the principle of effectiveness and of the right to effective judicial protection. ${ }^{73}$

Does the present ruling mean that Germany needs now to hear the message that the coercive measures it foresees are ineffective in terms of enforcing judgments based on EU law, under such a priori exceptional circumstances, and change its legislation and case-law? The mention of State liability proceedings, combined to the strength of air quality standards in EU law jurisprudence, is a hint in that direction.

In the end, the whole story leaves all parties and readers with a sour taste. The taste of the discrepancy between the apparently nice and good intentions of EU law and the difficulties to meet them in practice - the judgement might even encourage resistance to other diesel bans, the adequacy of which, it is worth recalling, was not challenged at all in the present case. It also adds the bitter flavour of persistent distortion between, on the one hand, the legitimate need to claim, maintain and enhance the protection of ambient air quality for the sake of protecting humans and, on the other hand, the difficulty to genuinely align transport policies with such same need to contribute to air quality

\footnotetext{
$71 \quad$ Para 38.

$72 \quad \mathrm{~N}^{\circ} 428403$, Amis de la Terre, available at https://www.conseil-etat.fr/ressources/decisions -contentieuses/dernieres-decisions-importantes/conseil-d-etat-10-juillet-2020-pollution -de-l-air.

Para 49.
} 
protection, a broad range of policies upon which EU law does also have a say. A sad tragicomedy in which, in the end, local official authorities are the dupes. They are left with not many other choices than to intervene and restrict the use of vehicles, even the use of those legally marketed and owned by their constituents.

At last, the case confirms that, would there be no resolute guardians like the non-governmental association to claim - thanks to crucial advances of international law on locus standi -74 the correct application of ambient air quality rules, even against the public authorities in charge, who else would, really? A very awkward and paradoxical situation in a European society where, as demonstrated by the COVID-19 sanitary crisis, it has now been made plain that public health ranks among our highest values.

74 J.Jendrośka, Access to Justice in the Aarhus Convention, op.cit. 